Portland State University

PDXScholar

\title{
A Conceptual Framework for Understanding Latent Demand: Accounting for Unrealized Activities and Travel
}

Kelly Clifton

Portland State University, kclifton@pdx.edu

\section{Recommended Citation}

Clifton, Kelly, "A Conceptual Framework for Understanding Latent Demand: Accounting for Unrealized Activities and Travel" (2017). TREC Friday Seminar Series. 118.

https://pdxscholar.library.pdx.edu/trec_seminar/118

This Book is brought to you for free and open access. It has been accepted for inclusion in TREC Friday Seminar Series by an authorized administrator of PDXScholar. Please contact us if we can make this document more accessible: pdxscholar@pdx.edu. 
胥 Portland State

\section{CONCEPTUAL FRAMEWORK FOR UNDERSTANDING LATENT DEMAND}

Accounting for Unrealized

Activities \& Travel

Kelly J. Clifton 


\section{Intro}

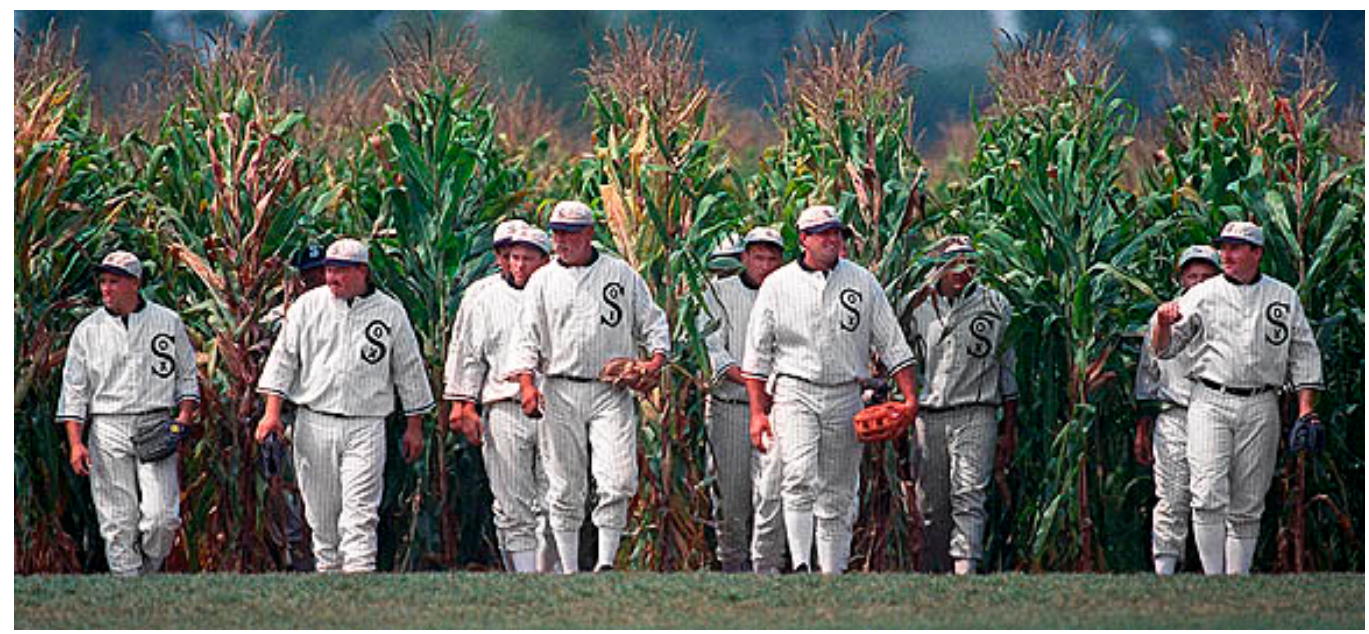

"Build it and they will come" argues that there is a "pent up" demand that will be activated by transportation improvements.

Most studies of latent $\&$ induced demand focus on traveler responses to changes in travel costs.

There has been little discussion of the underlying behavioral foundations of latent demand

A better definition of latent demand can aid in better forecasting, understand the consequences of unrealized travel, and identify where unmet demand is central to transportation policy. 


\section{Demand for transportation}

Transport demand is about the movement of people and goods.

It is considered a derived demand, which refers to demand for one good or service in one sector occurring as a result of demand from another.

Users of transport are primarily consuming the service because they wish to satisfy their needs (e.g. work, shopping, recreation) - or in the case of freight, the demand for

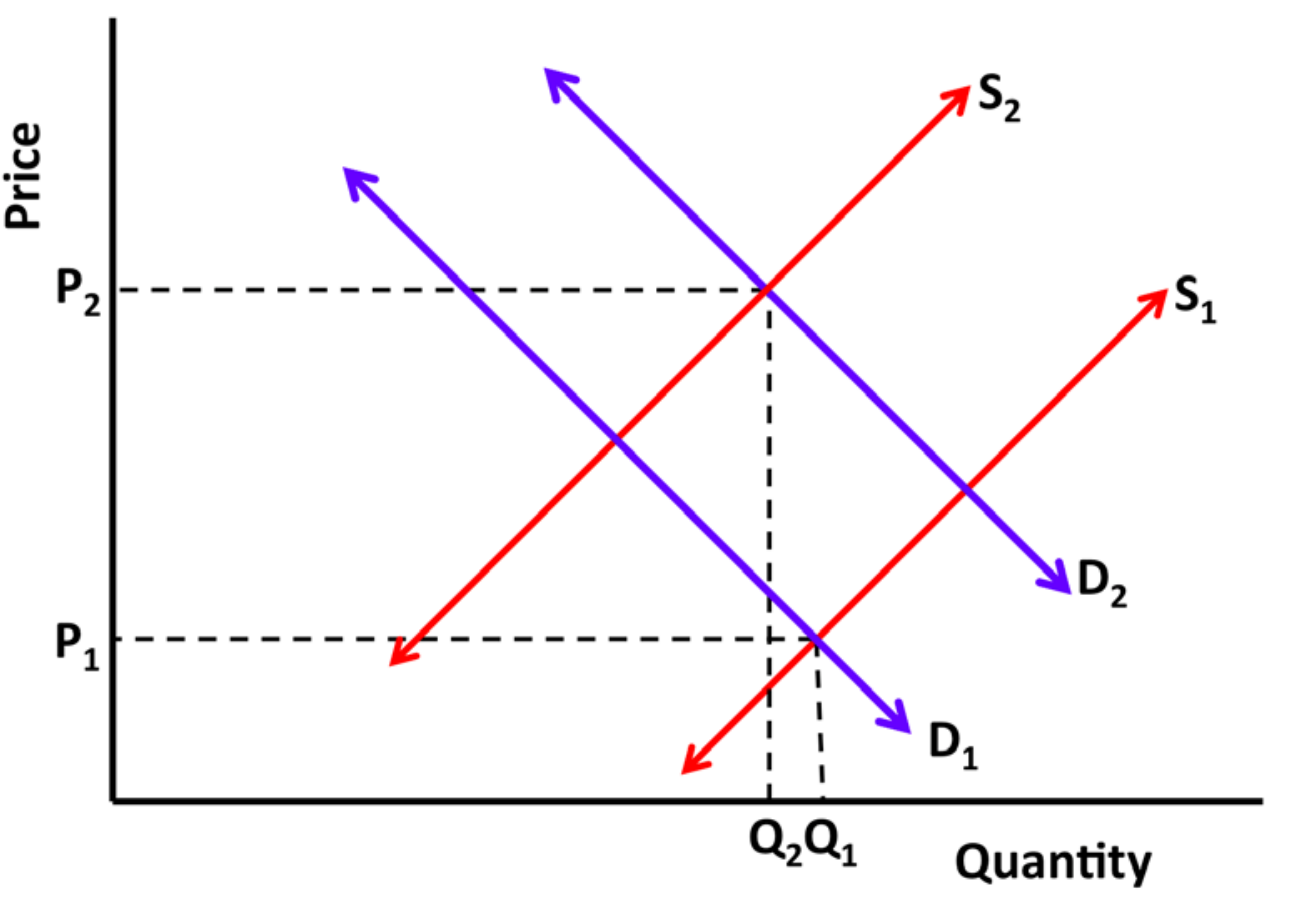
goods. 


\section{Latent (or Induced) Demand for Travel}

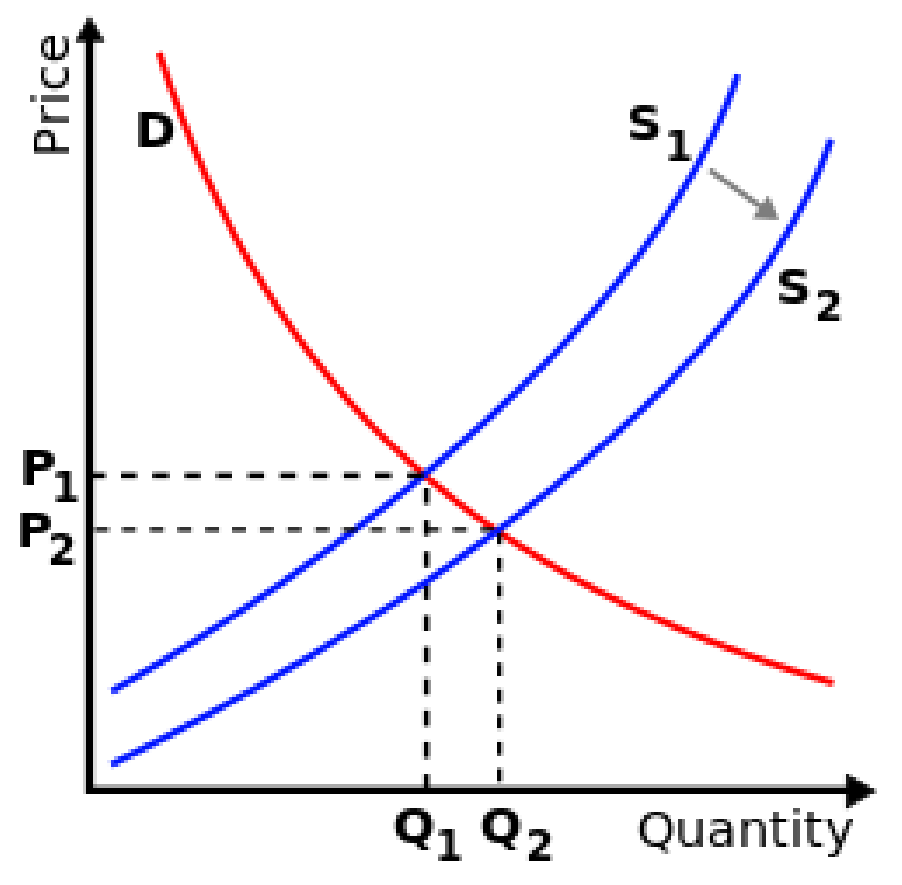

Latent demand represents currently desired demand that is not realized because of a wide variety of constraints.

Redistributed demand represents a rearrangement in space, time, destination, frequency and/or mode of the previously observed demand due to the relative changes in travel costs.

This represents our current approach to forecasting future travel needs - evaluating current demand based upon future predictions of the various explanatory factors.

Generative demand, are previously suppressed trips that can now be realized, presumably due to changes in the transportation system but perhaps due to exogenous social, economic, cultural and technological drivers. 


\section{Demand models are estimated using data on observed trips}

Where did you go?

\section{START HERE}

Place 1: Where were you at 4:00 AM on your assigned travel day?

Provide place name and addressintersection: Home

Place 2: Where did you go next? Provide place name and addressintersection: Work - Arbor Law Firm

990 Central Ave, Chicago, It 60639

Place 3: Where did you go next?

Provide place name and address:intersection

Gustoso's Pizza

1800 Kerry Lane, Chicago, IL 60639

What about unmade trips?
Place 4: Where did you go next?

Provide place name and addressintersection

Work - Arbor Law Firm

990 Central Ave, Chicago, IL 60639

Place 5: Where did you go next?

Provide place name and addressintersection:

Fairview Elementary

7590 North Rd. Chicago IL 60639

Place 6: Where did you go next?
How did you get there?

What time did How did you get How many you arrive at this place?

How did you get
to this place?

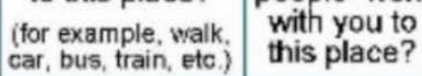

What time did
you leave this

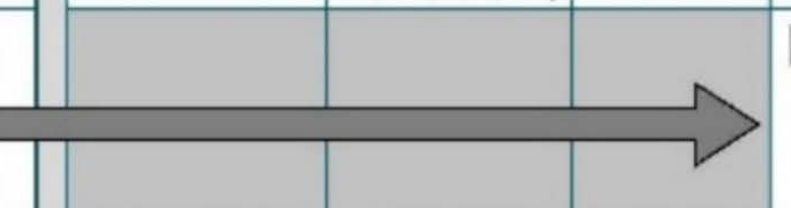

$7,3,1$ $X$ AM $\square P M$

$\square$ Did not leave

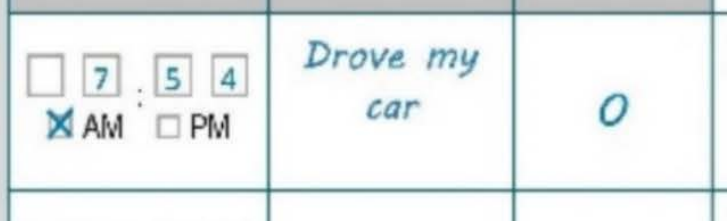

(1) $4 \sqrt{5}$

口AM XPI

$\square$ Did not leave

(1) 2.58

$\square$ AM $X \mathrm{PM}$

Walked

- Ald X PII

$\square 2,0,2$

$\square \mathrm{AM} X \mathrm{PM}$

$\square$ 5. 0.8

$\square$ AM $X P M$

Drove my
car

Walked

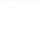

1. $4 \sqrt{5}$

$\square$ AM $X P M$

$\square$ Did not leave

$\square$ 4. 5,2

$\square A M \times P M$ $\square$ Did not leave

$\square$ 5.2 0

DAM $X \mathrm{PM}$

$\square$ Did not leave
What did you do?

What did you do

at this place?

Use the Activity List

07. Ate

breakfast and

got ready for

work

03. Work

13. Buy and

eat lunch

03. Work
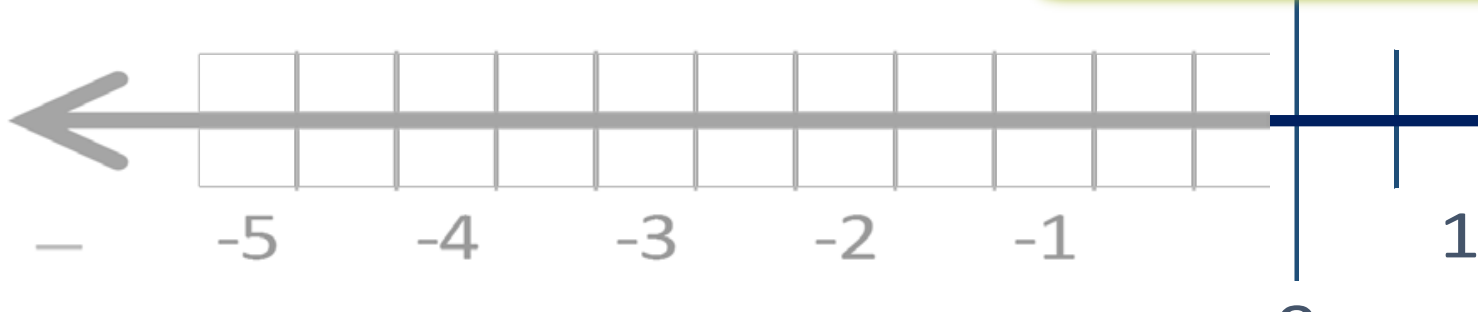

1

2

3

4 


\section{One Travel Day Planned}

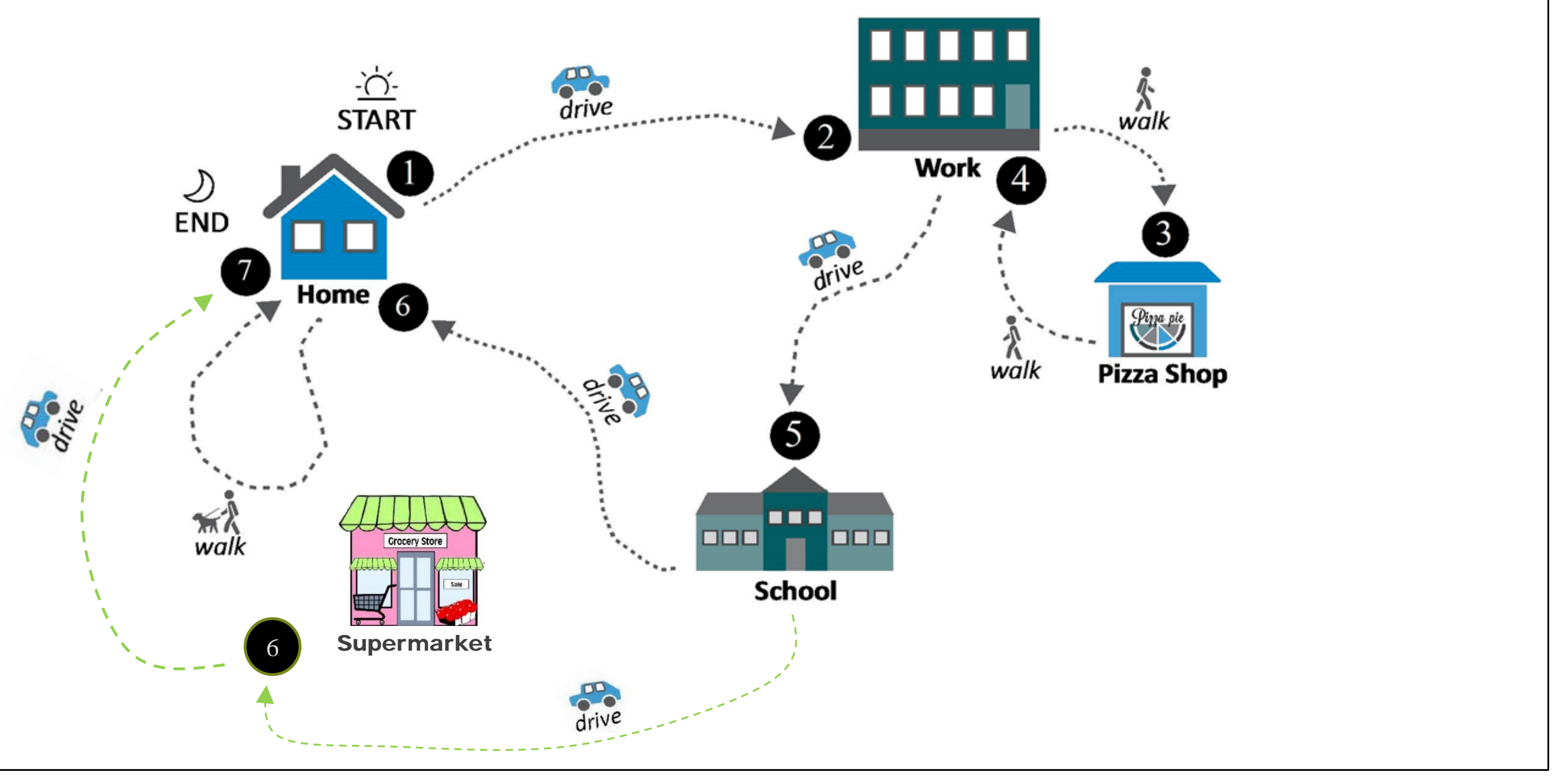




\section{Next Travel Day Planned}

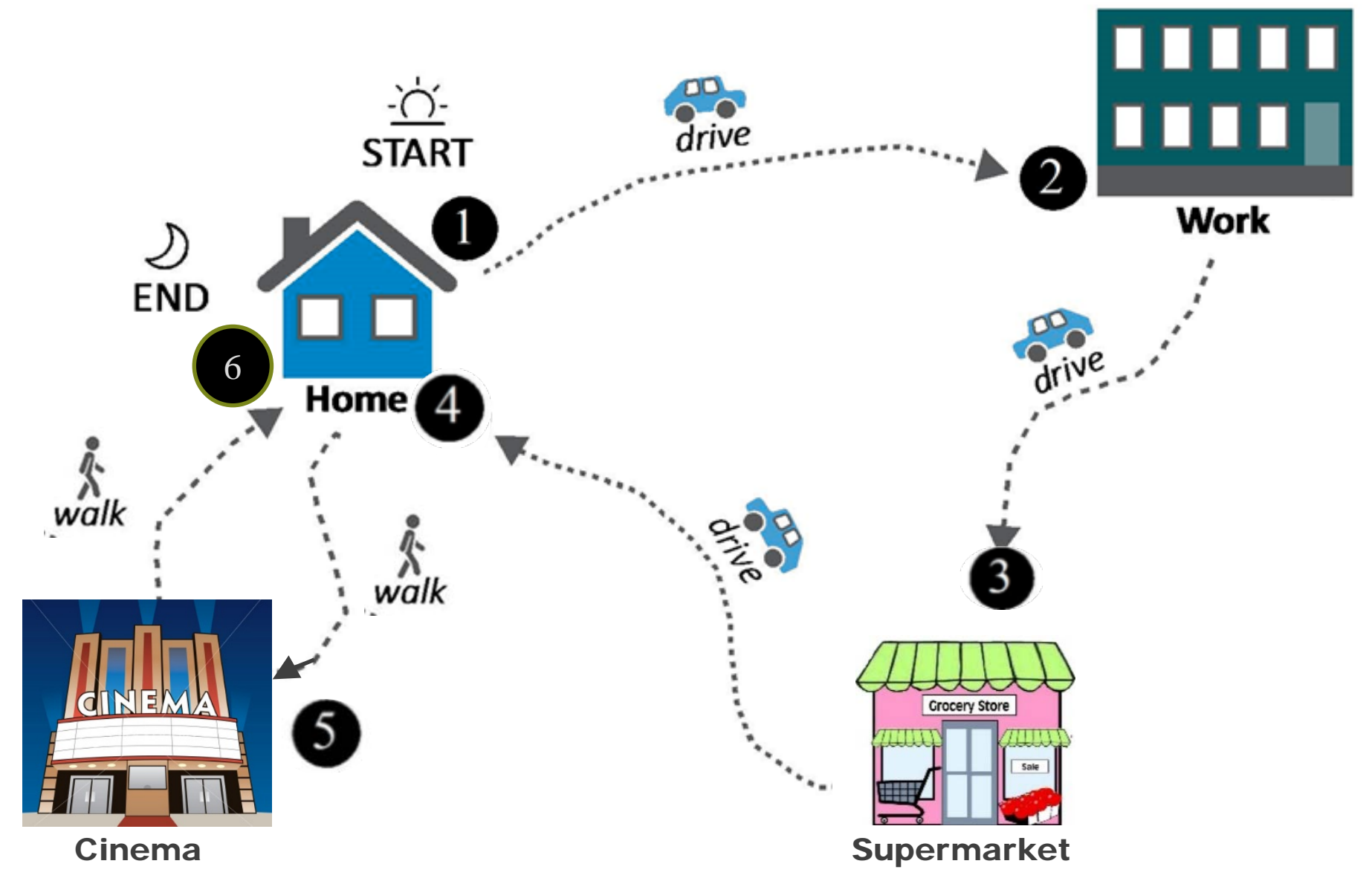




\section{Rationale for this work}

What?

Explore the idea of latent demand through the lens of unmet activities and ultimately travel

Why?

A better definition and quantification of this idea can help to:

- better predict the impact of transportation investments,

- Anticipate response to social, technological, cultural and economic change

- help identify inequities,

- understand the consequences of these unmet demands and

- determine to what degree this unmet demand is a matter for transportation policy.

How?

Develop a theoretical framework $\&$ approach to data collection 


\section{Other Definitions of Latent Demand}

Induced demand, or latent demand, is the phenomenon that after supply increases, more of a good is consumed. -Wikipedia

Demand for a product or service that a consumer cannot satisfy because they do not have enough money, because the product or service is not available, or because they do not know that it is available. - Cambridge Dictionary

Latent demand is basically the desire for a product that a consumer is unable to satisfy because he is himself unable to point it out or doesn't realize what is missing until pointed out. -MBASkool

"In contrast to definitions of expressed demand based upon observable buying behavior, the concept of latent demand pertains to those with an interest in participation or "purchase"; who have not translated that interest into action." Richardson \& Cromption 


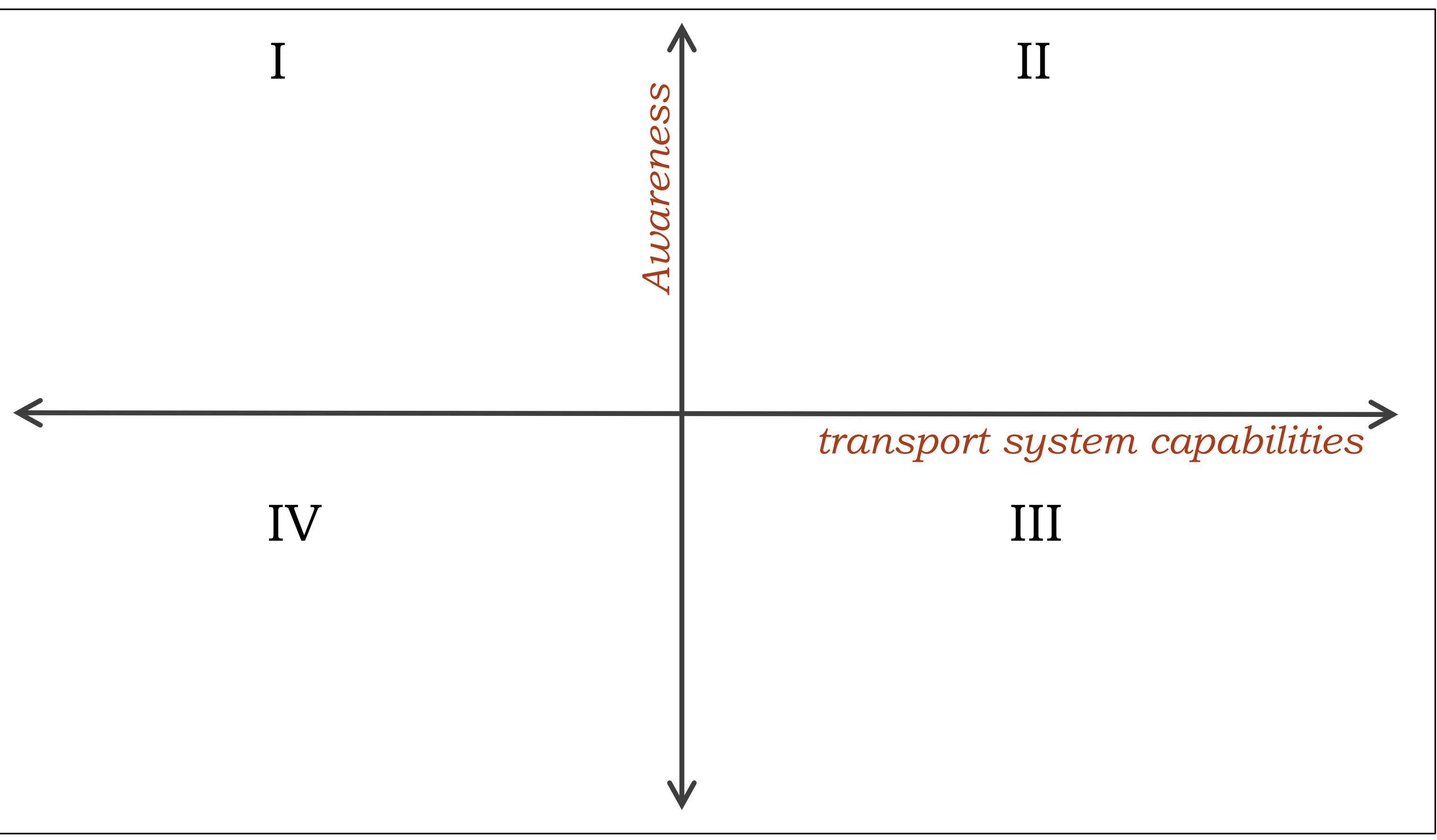




\section{I}

- Activities are desired

- Transport system cannot accommodate

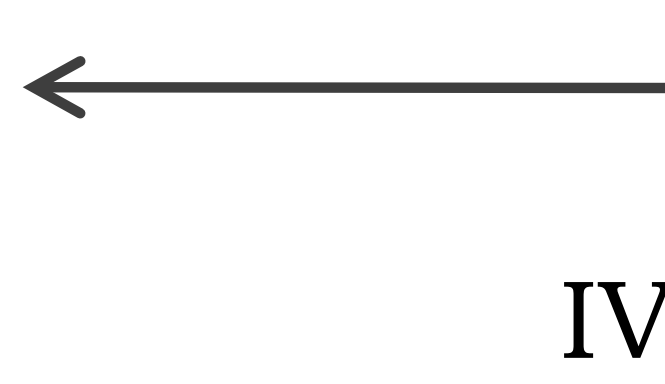

transport system capabilities

IV

III 


\section{Examples}

- Spatial or temporal gaps in transit service

- Travel times lead to time poverty

- No access to automobiles

- No internet access

- Food deserts

- No sidewalk infrastructure

- Lack of bicycle network

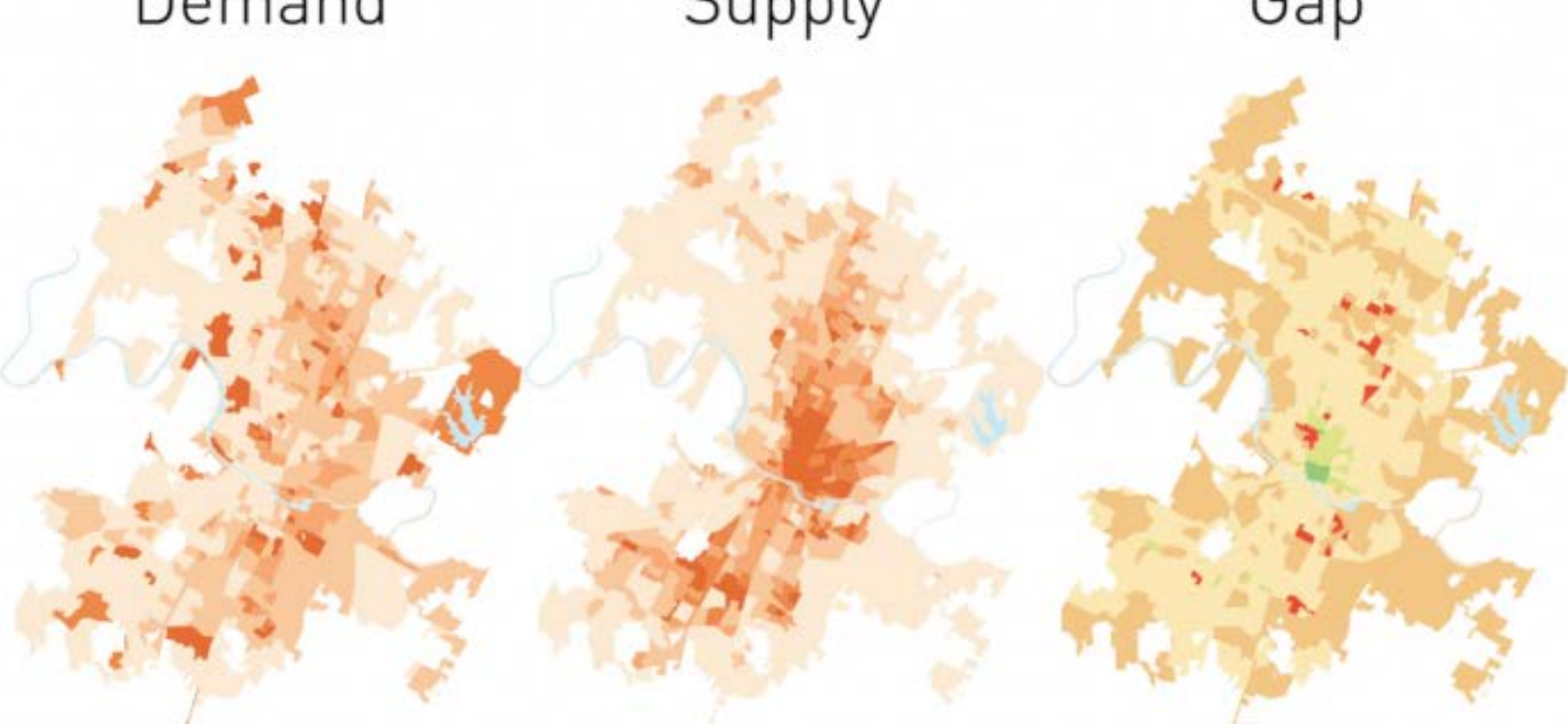

Junfeng Jiao and Aaron Nichols (2015) Identifying Transit Deserts in Texas Cities: The Gap Between Supply and Demand. University of Texas at Austin, Center for Sustainable Development, Working paper series connectivity 
I

- Activities are desired

- Transport system cannot accommodate

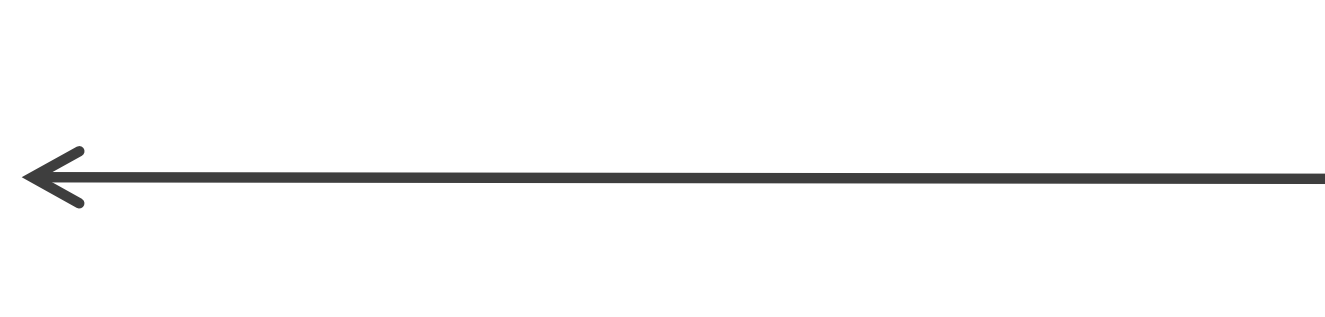

IV

\section{II}

- Activities are desired

- Transport system can accommodate

- Other barriers exist transport system capabilities

\section{III}




\section{Examples}

- Poverty

- Activity schedule leads to time poverty (too busy)

- Scheduling conflicts

- Social exclusion

- Cultural barriers

- Lack of work experience or education

- Discrimination

- Housing costs limit choices

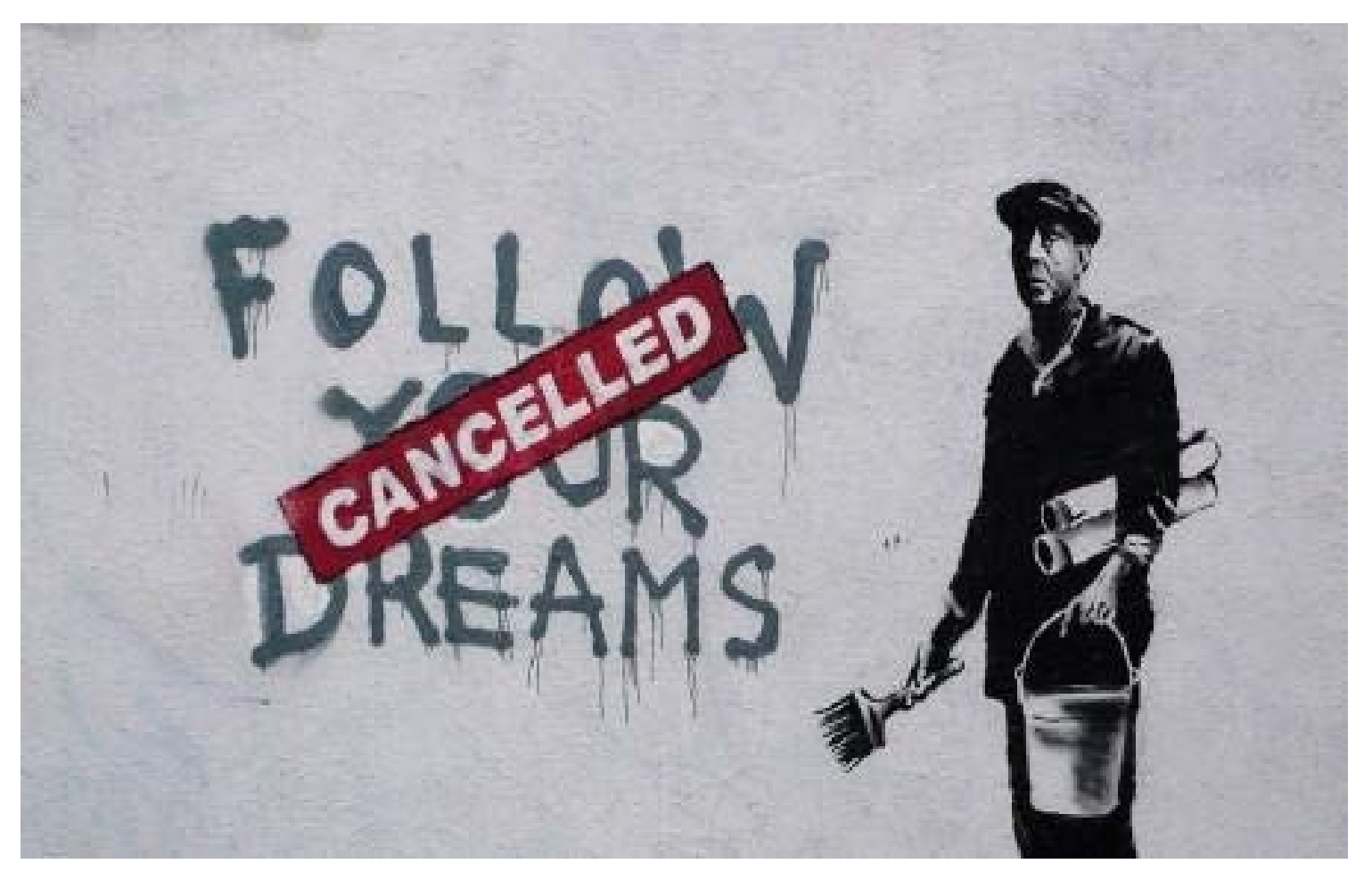


I

- Activities are desired

- Transport system cannot accommodate

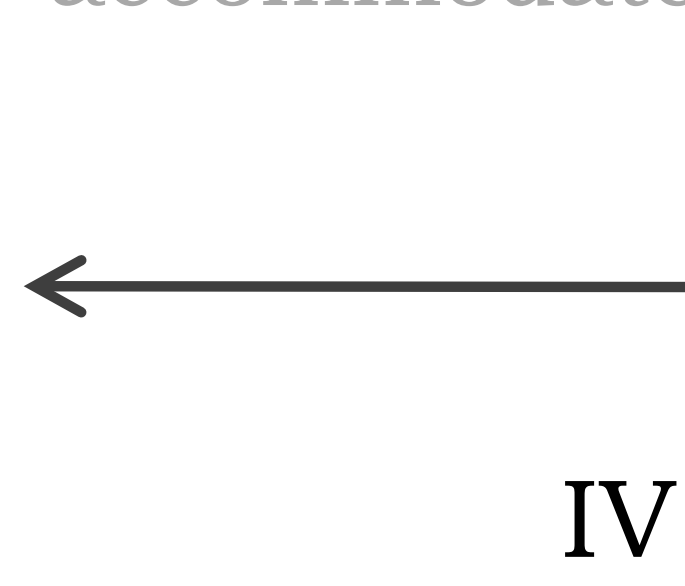

II

- Activities are desired

- Transport system can accommodate

- Other barriers exist transport system capabilities

\section{III}

- Activities are not desired

- Transport system can accommodate 


\section{Examples}

- Mode exists but unaware of how to use it or where it goes

- Not (currently) motivated to engage in an activity

- Yet untried activity: Who knew I would love Stand Up Paddle Boarding?

- Unaware of new restaurant opening

- Surprise visit from a friend
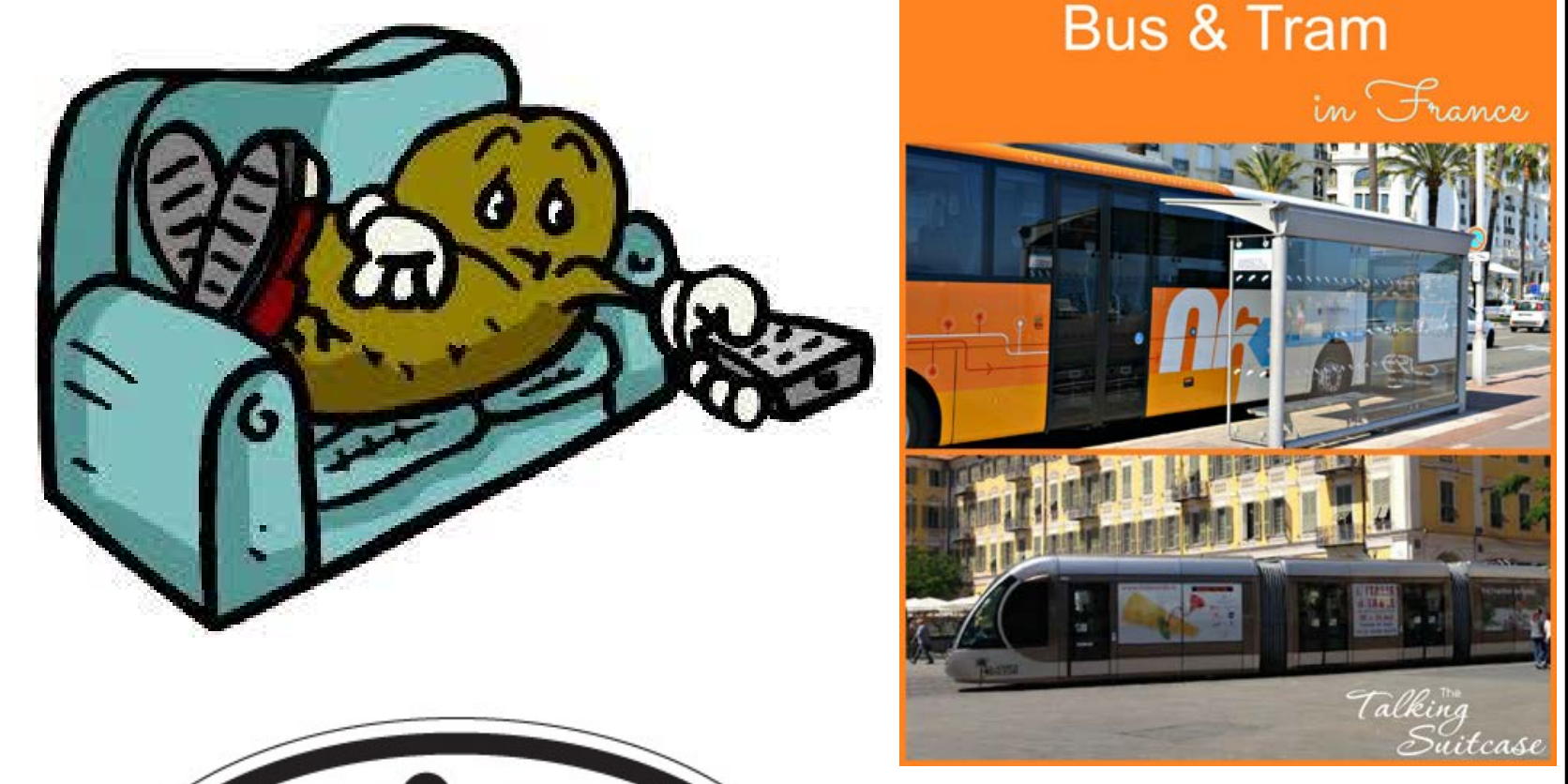
taking you to lunch

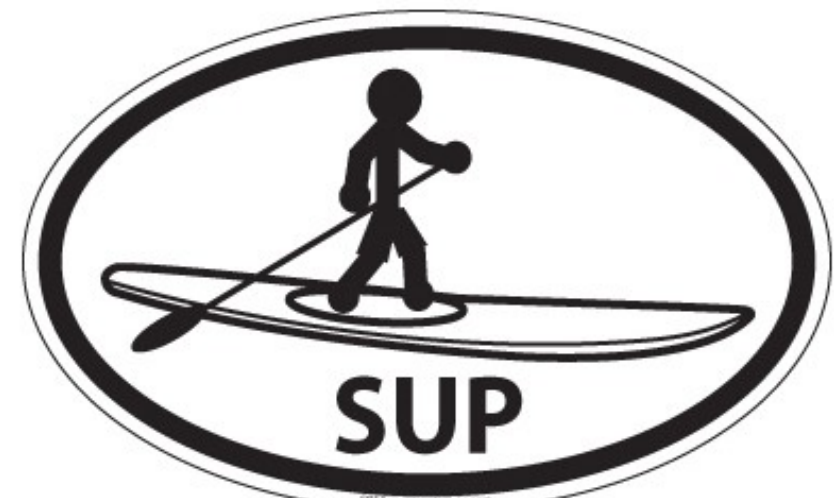


I

- Activities are desired

- Transport system cannot accommodate

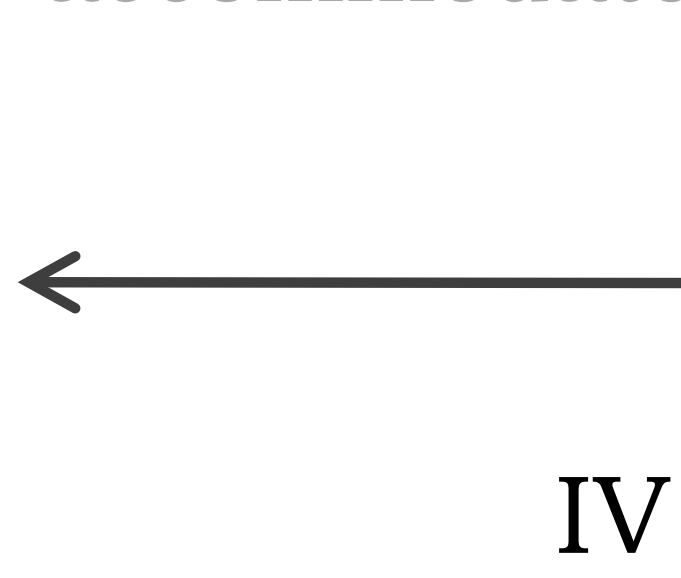

- Activities are not desired

- Transport system cannot accommodate
II

- Activities are desired

- Transport system can accommodate

- Other barriers exist transport system capabilities

\section{III}

- Activities are not desired

- Transport system can accommodate 


\section{Examples}

Future modes:

- Driverless vehicles

- Teleportation

- Hovercraft

- SpaceX Hyperloop

- Drone delivery

- 3-D Printing

- Etc.

Previously (say in 1980):

- Online shopping

- Uber

- Smart phones

- Etc.

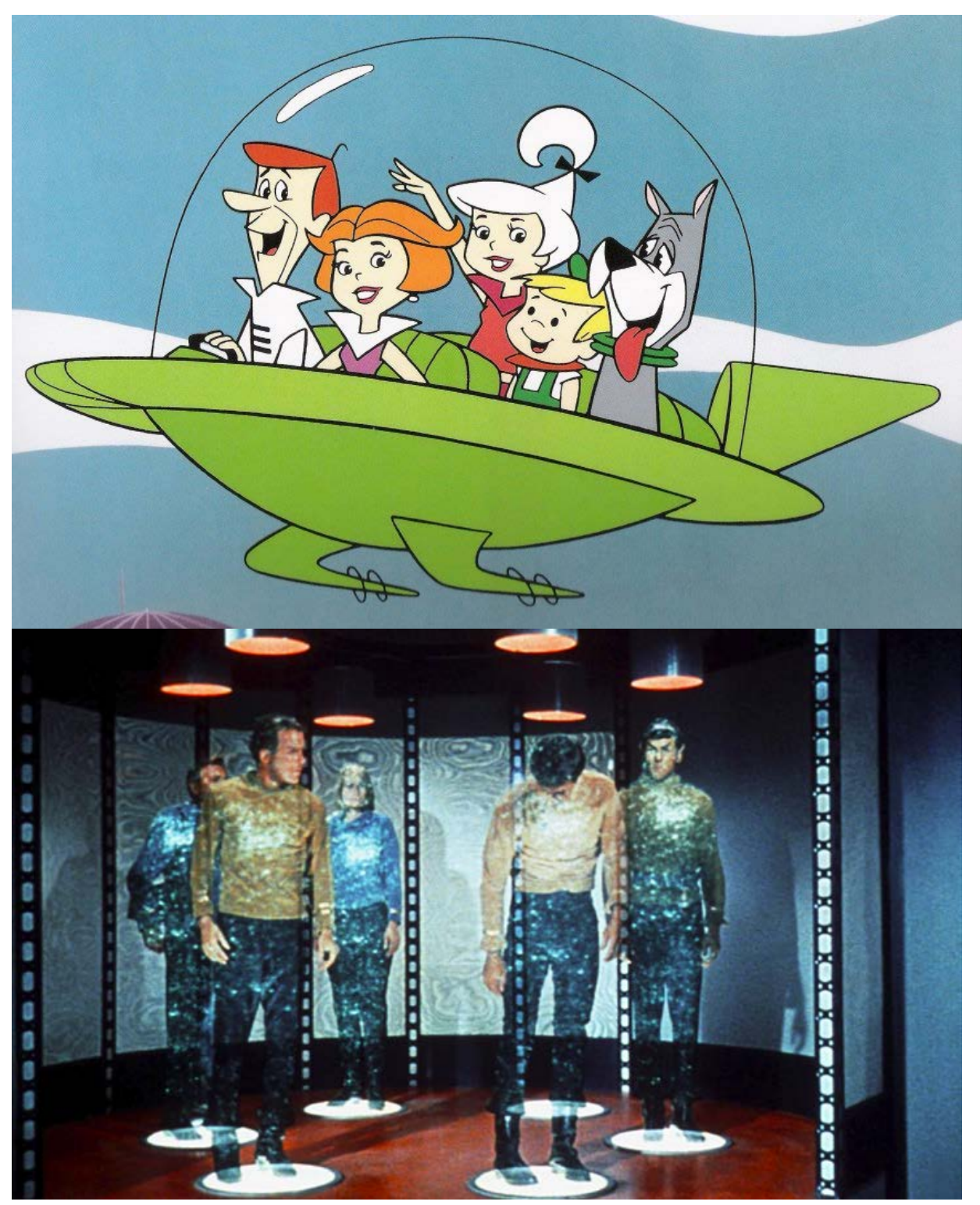




\section{I}

- Activities are desired

- Transport system cannot accommodate

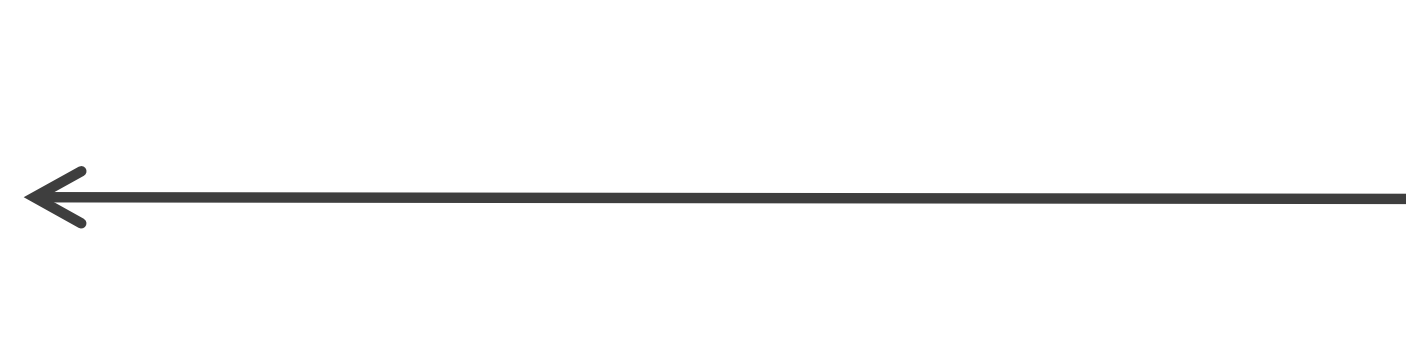

\section{IV}

- Activities are not desired

- Transport system cannot accommodate

\section{II}

- Activities are desired

- Transport system can accommodate

- Other barriers exist transport system capabilities

\section{III}

- Activities are not desired

- Transport system can accommodate 
How might we capture these various types of latent demand? 


\section{I}

- Activities are desired

- Transport system cannot accommodate

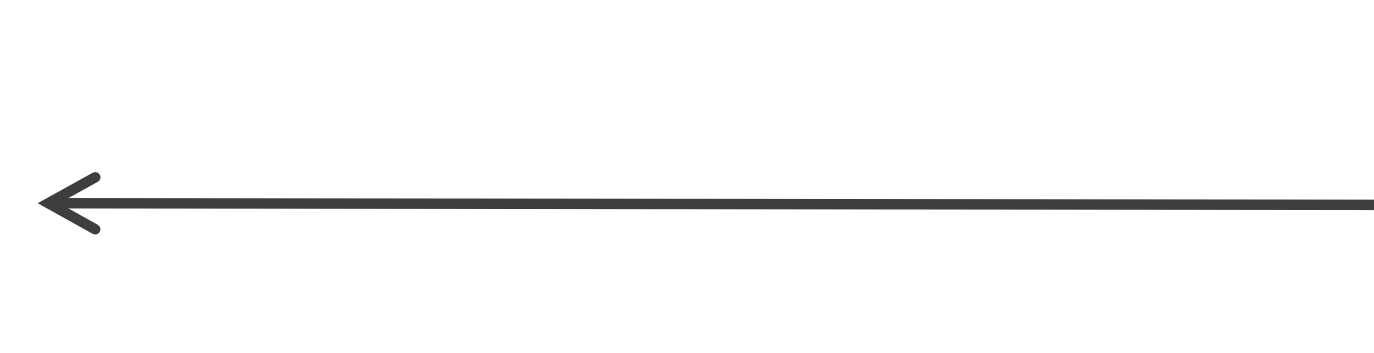

IV

\section{II}

- Activities are desired

- Transport system can accommodate

- Other barriers exist

transport system capabilities

\section{III}




\section{One Travel Day Planned}
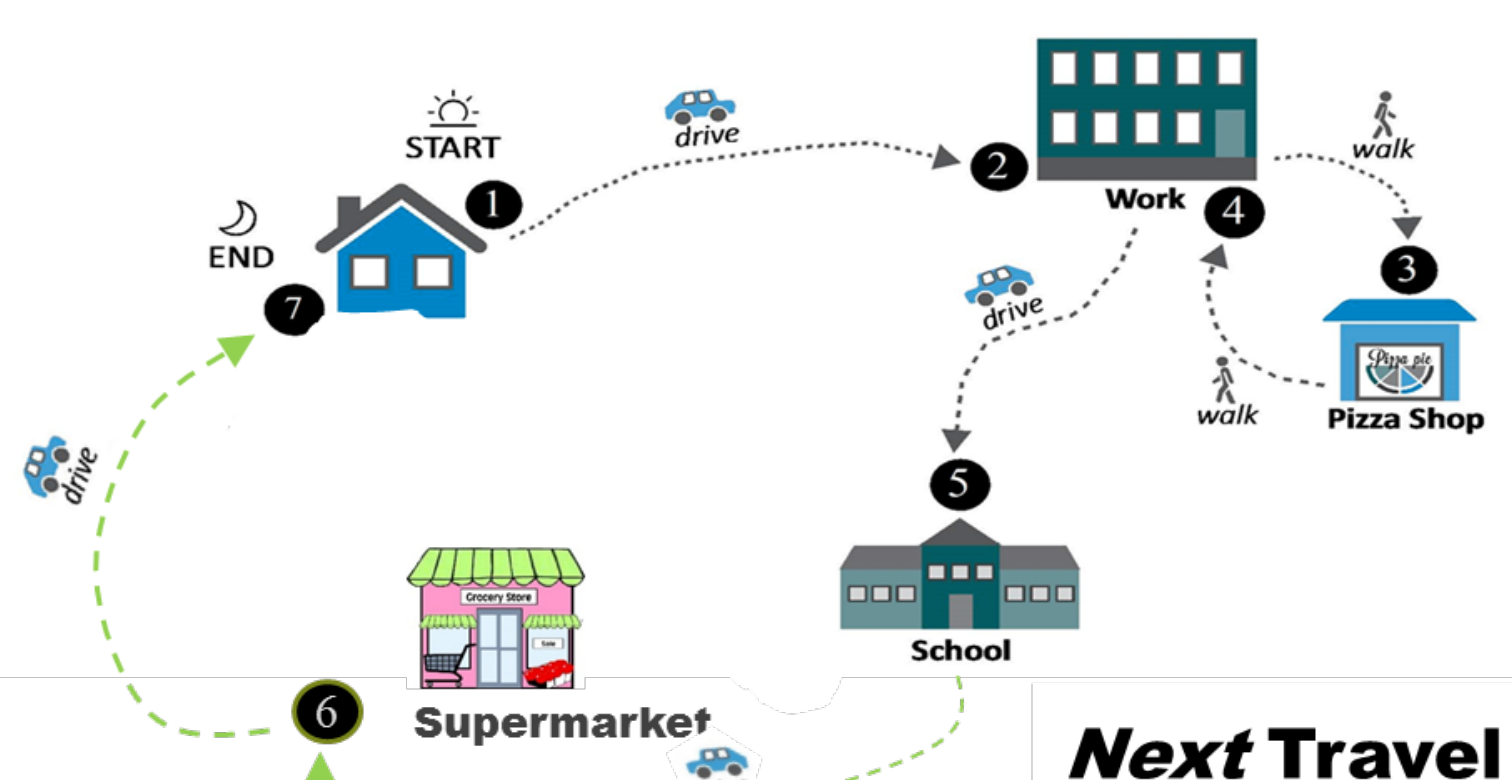
我
Next Travel Day Planned

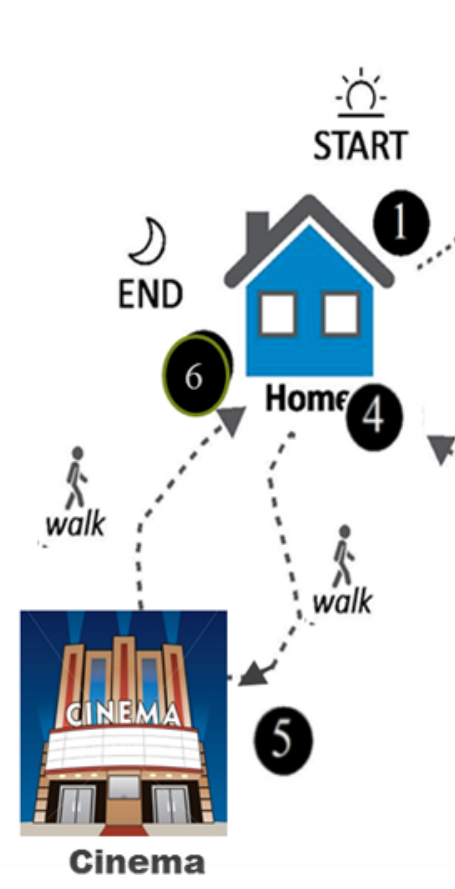

\section{One Travel Day Observed}

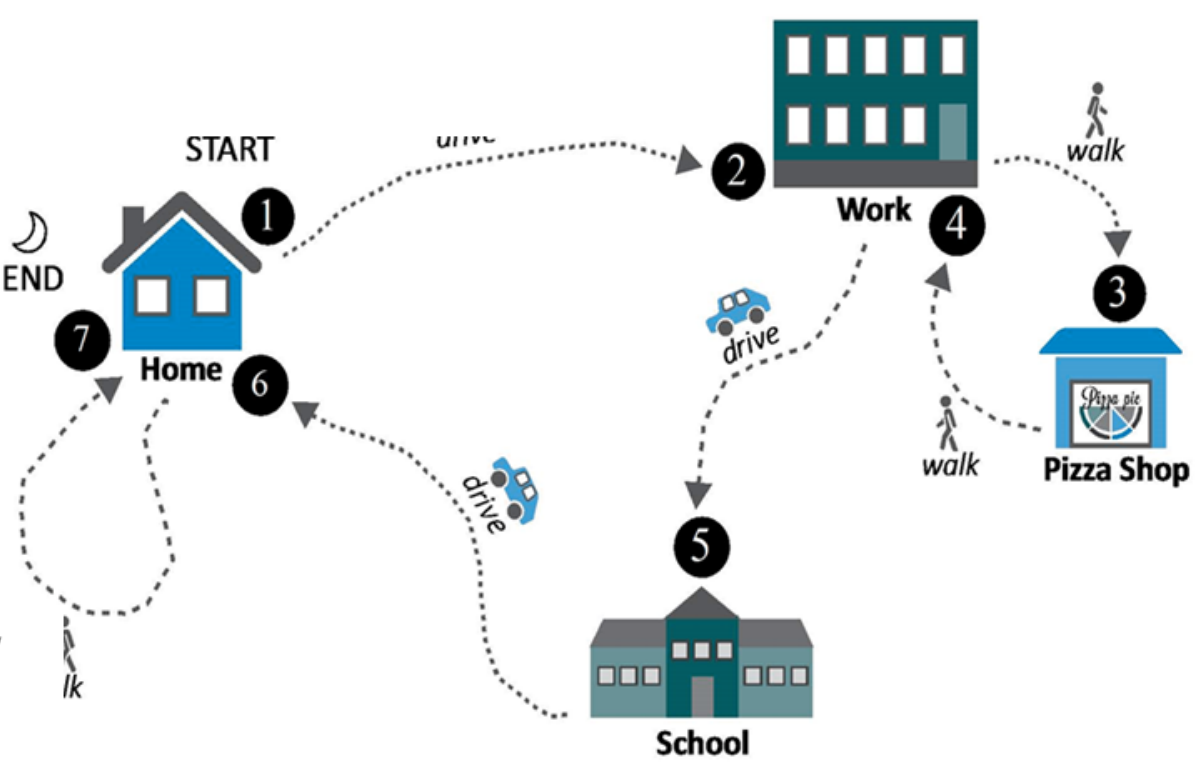




\section{Activity, travel, attitudes, \& preferences (multi-day)}

\begin{tabular}{|c|c|c|c|c|c|}
\hline \multirow{2}{*}{$\begin{array}{l}\text { Where did you go? } \\
\text { START HERE }\end{array}$} & \multicolumn{3}{|c|}{2 How did you get there? } & \multicolumn{2}{|c|}{4 What did you do? } \\
\hline & $\begin{array}{l}\text { What ime did } \\
\text { you arive at this } \\
\text { place? }\end{array}$ & 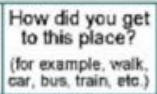 & $\begin{array}{l}\text { How many } \\
\text { people went } \\
\text { with yout } \\
\text { this place? }\end{array}$ & $\begin{array}{l}\text { What time did } \\
\text { you leave this } \\
\text { place? }\end{array}$ & $\begin{array}{l}\text { What did you do } \\
\text { at inis place? } \\
\text { Use the Aclinty List } \\
\text { beliex }\end{array}$ \\
\hline $\begin{array}{l}\text { Place 1: Where were you at 4:00 AM } \\
\text { on your assigned travel day? }\end{array}$ & & & & $\begin{array}{l}\square 7 \\
\times A M\end{array}$ & $\begin{array}{l}\text { Or. Ate } \\
\text { breakfast and }\end{array}$ \\
\hline Home & & & & $\square$ Did not leave & 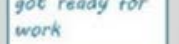 \\
\hline $\begin{array}{l}\text { Place 2: Where did you go next? } \\
\text { Provide place name ond addressintersection: } \\
\text { Work - AAbbor Law Firm } \\
990 \text { Centrel Ave, Chicago, IL } 60639\end{array}$ & $\begin{array}{l}7 \\
\times \text { AM }\end{array}: \frac{5}{\square} \sqrt{4}$ & $\begin{array}{l}\text { Drove my } \\
\text { car }\end{array}$ & 0 & 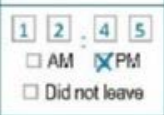 & 03. Work \\
\hline 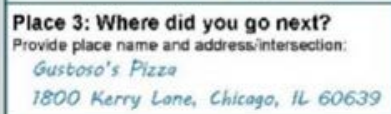 & 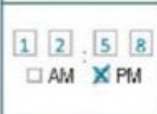 & Walked & 2 & $\begin{array}{l}\square 1:: 4: 5 \\
\square \text { AM } \times \text { PM } \\
\square \text { Did not leave }\end{array}$ & $\begin{array}{l}\text { 73. Buy and } \\
\text { eat lunch }\end{array}$ \\
\hline 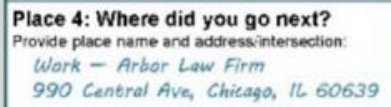 & $\begin{array}{l}\square 2 \\
\square \text { ANA }: \frac{012}{X P M}\end{array}$ & Walked & 2 & 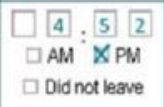 & 03. Work \\
\hline $\begin{array}{l}\text { Place 5: Where did you go next? } \\
\text { Provide place name and addressintersection: } \\
\text { Fairview Elementeary } \\
7590 \text { North Rd. Chicago IL. } 60639\end{array}$ & $\begin{array}{l}5 \\
\square A M\end{array}: \frac{0}{8}$ & $\begin{array}{l}\text { Drove my } \\
\text { car }\end{array}$ & 0 & $\begin{array}{l}\square 5: 2,0 \\
\square \text { AM }: 2 \text { PMM } \\
\square \text { Did not leave }\end{array}$ & $\begin{array}{l}\text { 06. Pick up } \\
\text { daughter from } \\
\text { school }\end{array}$ \\
\hline Place 6: Where did you go next? & & Drove my & & $\square 7.30$ & O1. Ate dinner \\
\hline
\end{tabular}

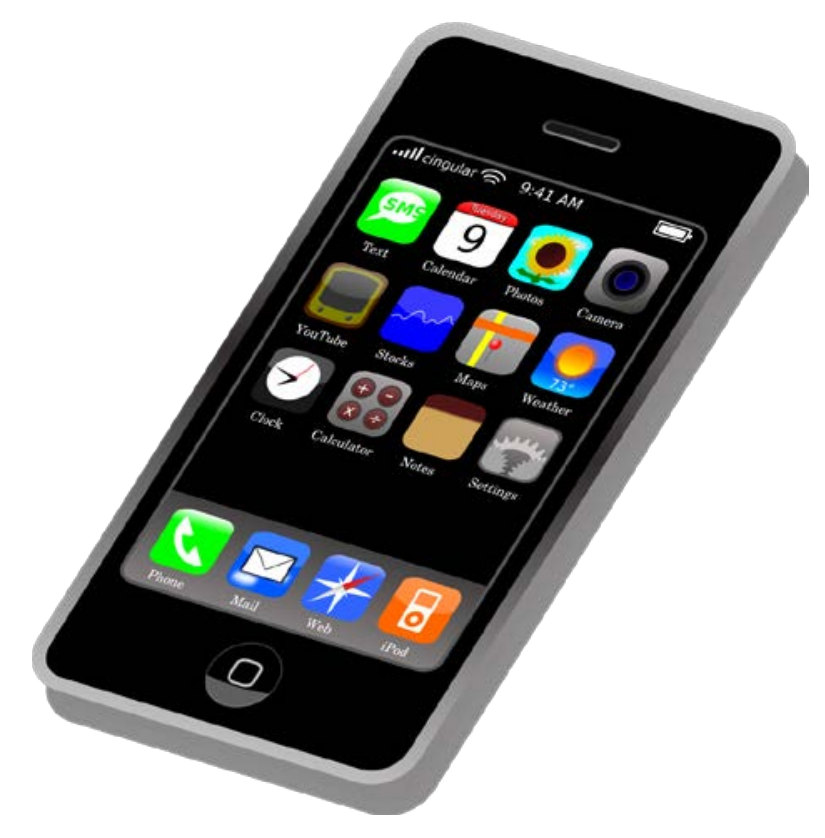




\section{Activity, travel, attitudes, \& satisfaction (multi-day)}
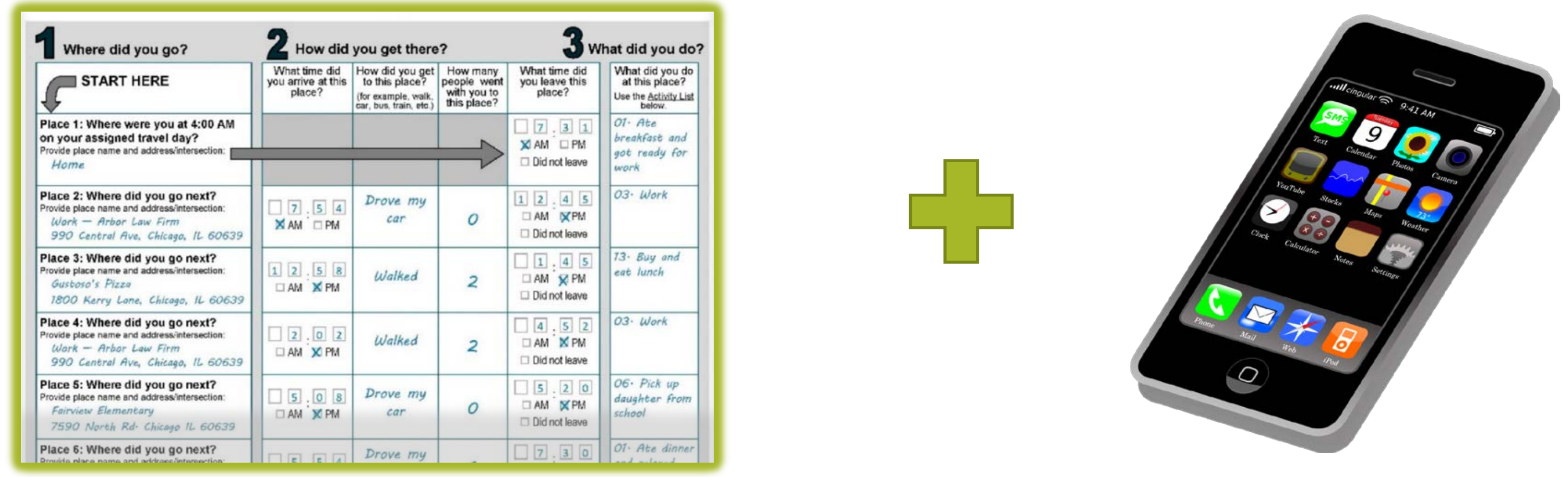

But not enough for unmade trips \& unrealized activities

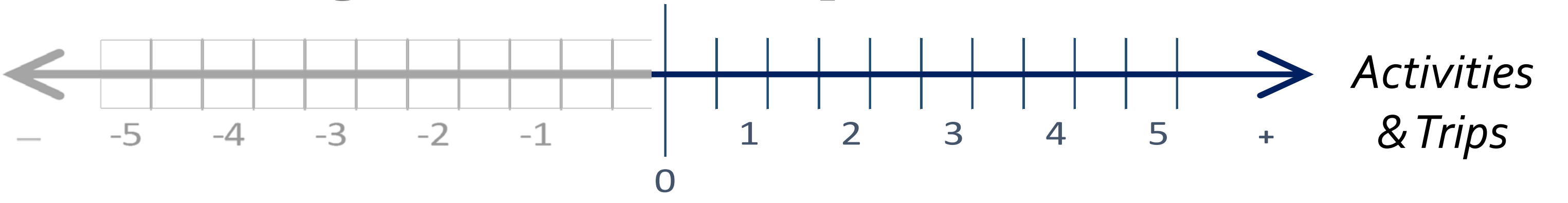




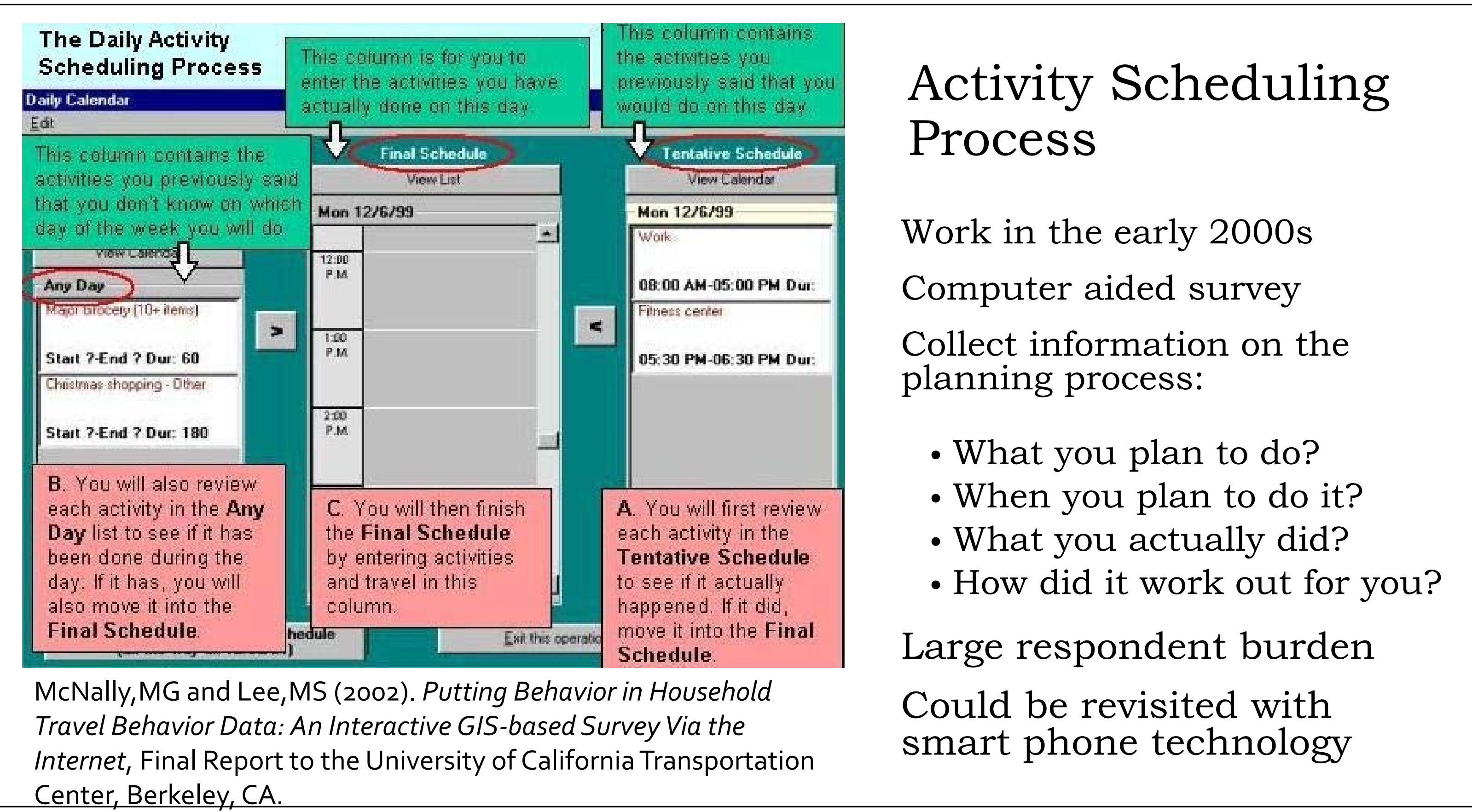




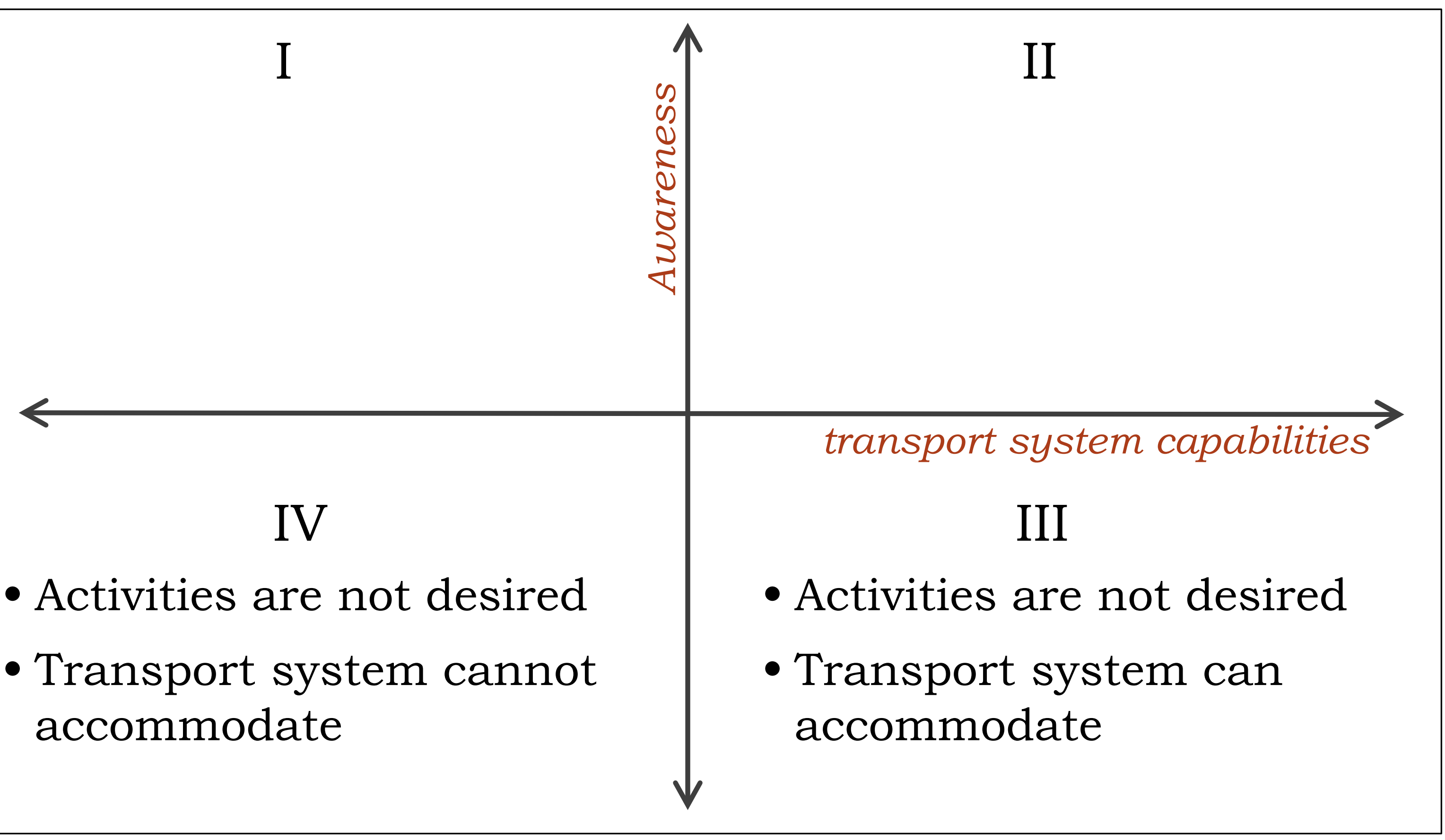




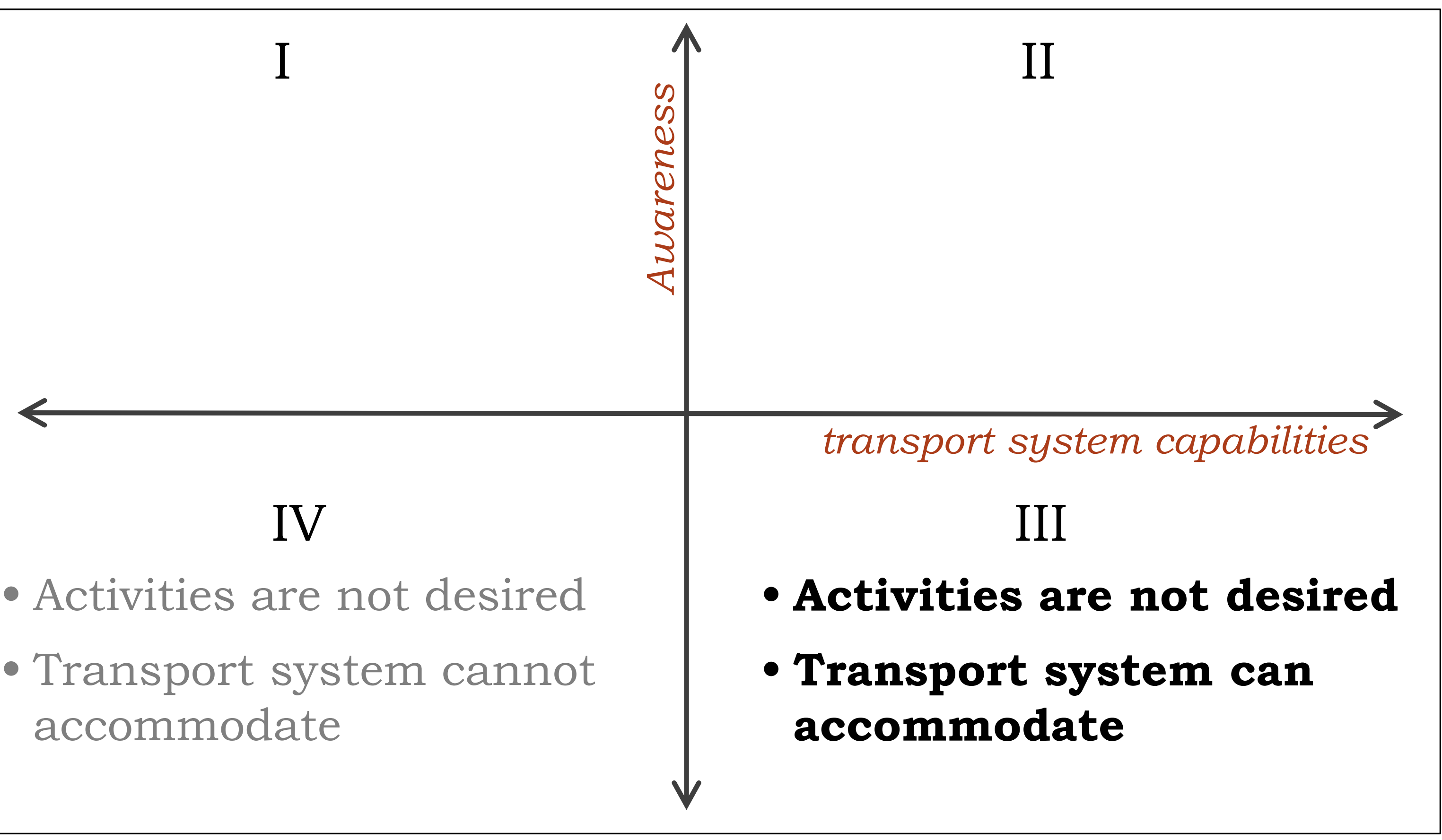




\section{Behavioral change}

If the public is not aware of existing options or not motivated to use them, programs can work to address the gaps

Drawing upon research in health disciplines:

- Education/Awareness

- Information

- Motivation

- Support

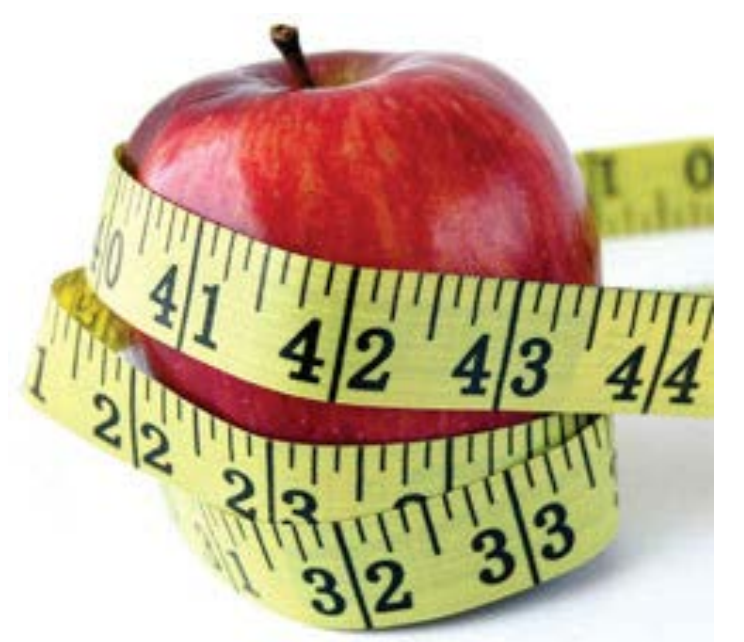

Public campaigns to reduce driving, learn how to use transit, ride a bike, encourage walking.
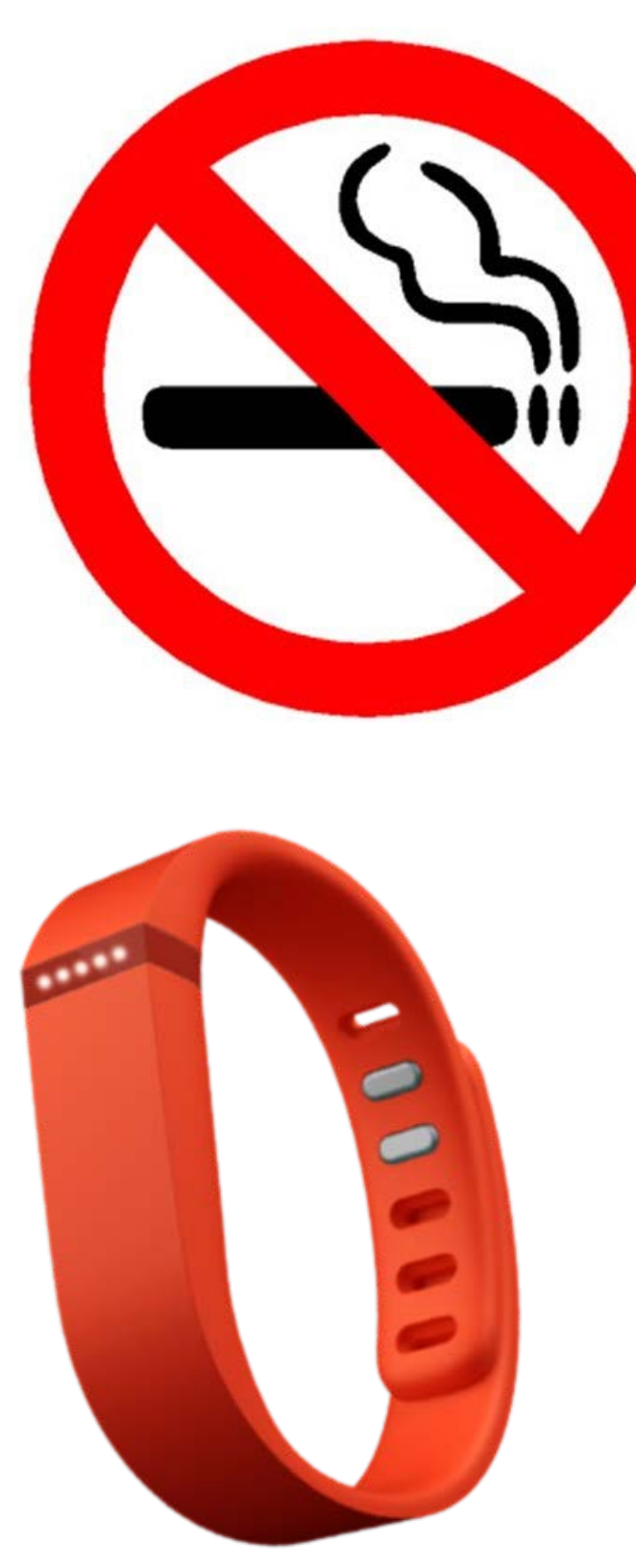


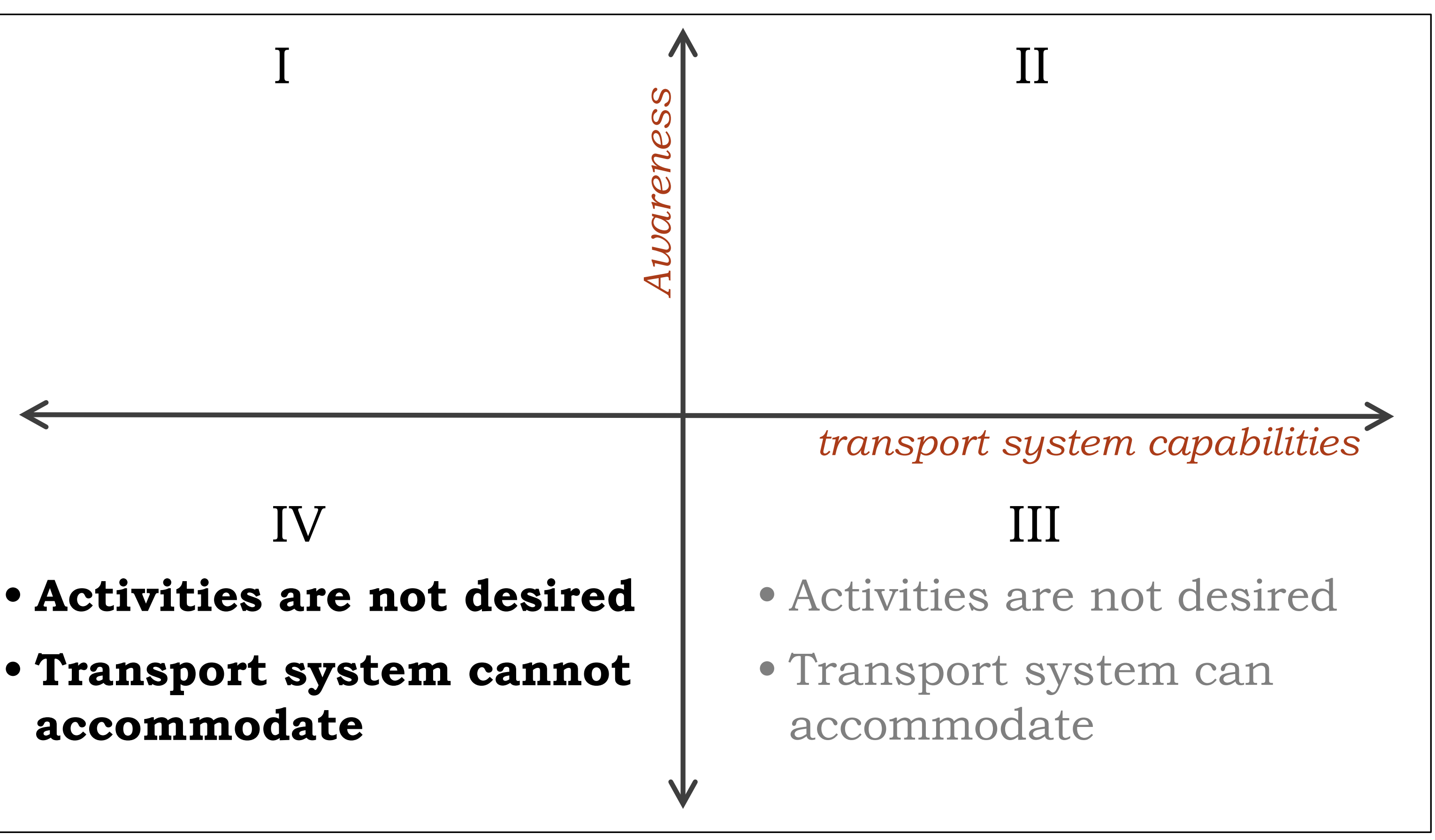




\section{Stated Preference Surveys}

\section{Option A}

Cost: $\$ 2.50$

Travel time: 30 minutes

Share ride with others

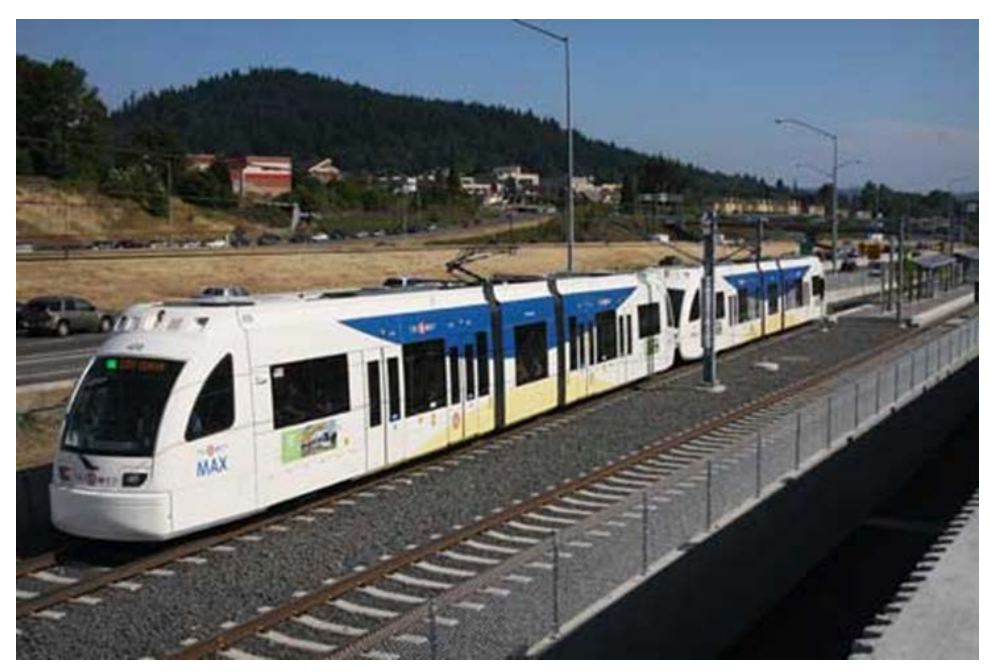

\section{Option B}

Cost: $\$ 12$

Travel time: 20 minutes Have vehicle to yourself

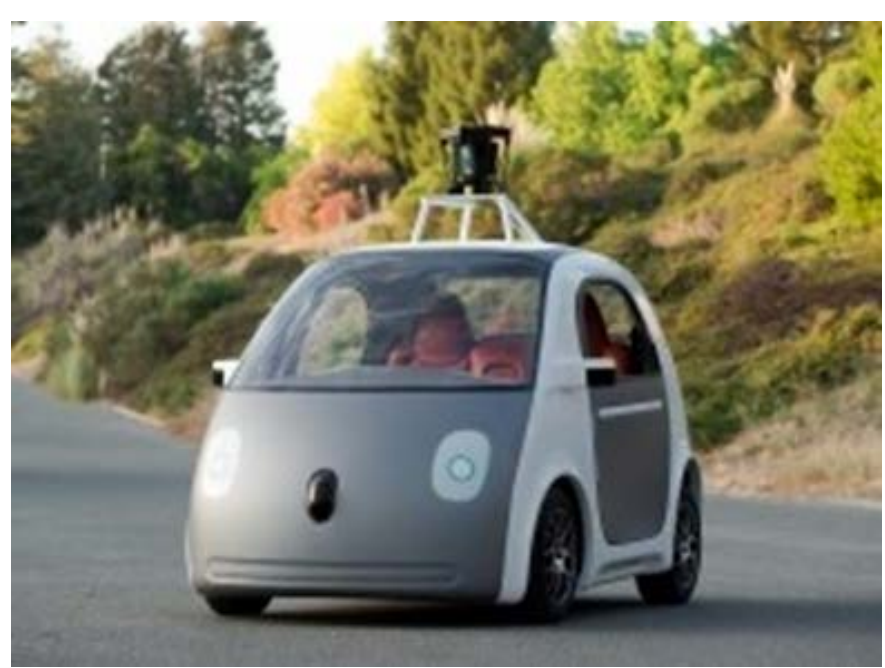




\section{What are the drivers of the demand for activities \& travel?}

- What motivates us?

- Psychology \& other behavioral disciplines have a lot to offer

- Might be important to understand how we might respond to new opportunities in the future

- Marketing discipline has made use of this research

- They induce demand for products

- What can we learn here?

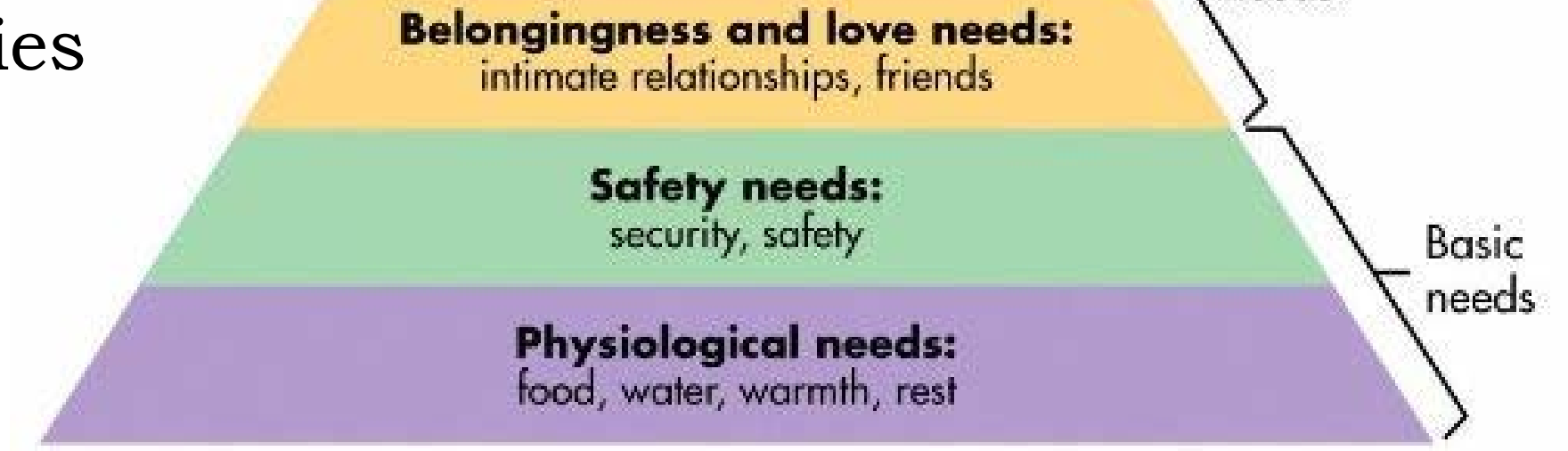

Maslow, A. H. (1943). A Theory of Human Motivation. Psychological Review, 50(4), 370-96.

Belongingness and love needs: intimate relationships, friends

Safely needs:

Physiological needs:

food, water, warmth, rest
Self-fulfillment needs

actualization:

achieving one's

full potential,

including creative activities

Esteem needs: prestige and feeling of accomplishment

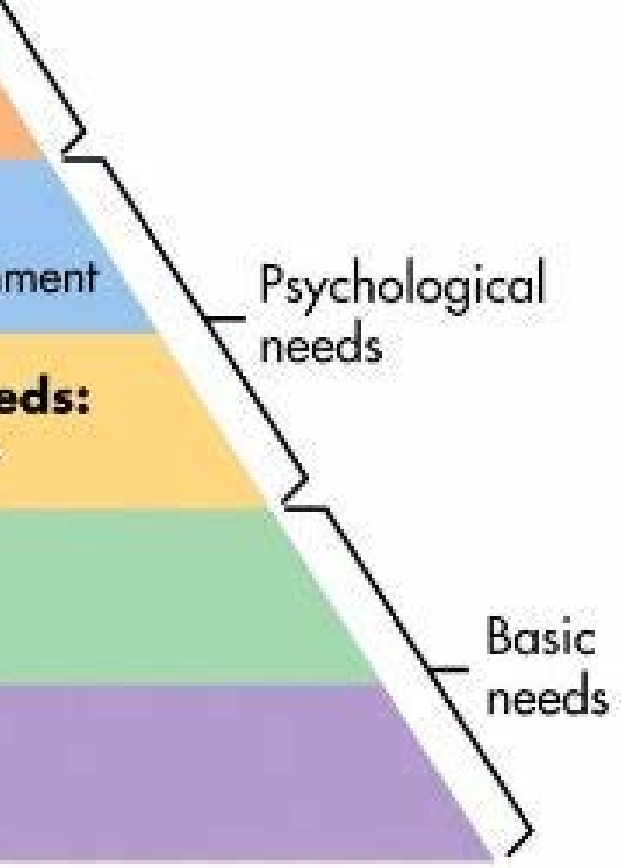

Psychological 


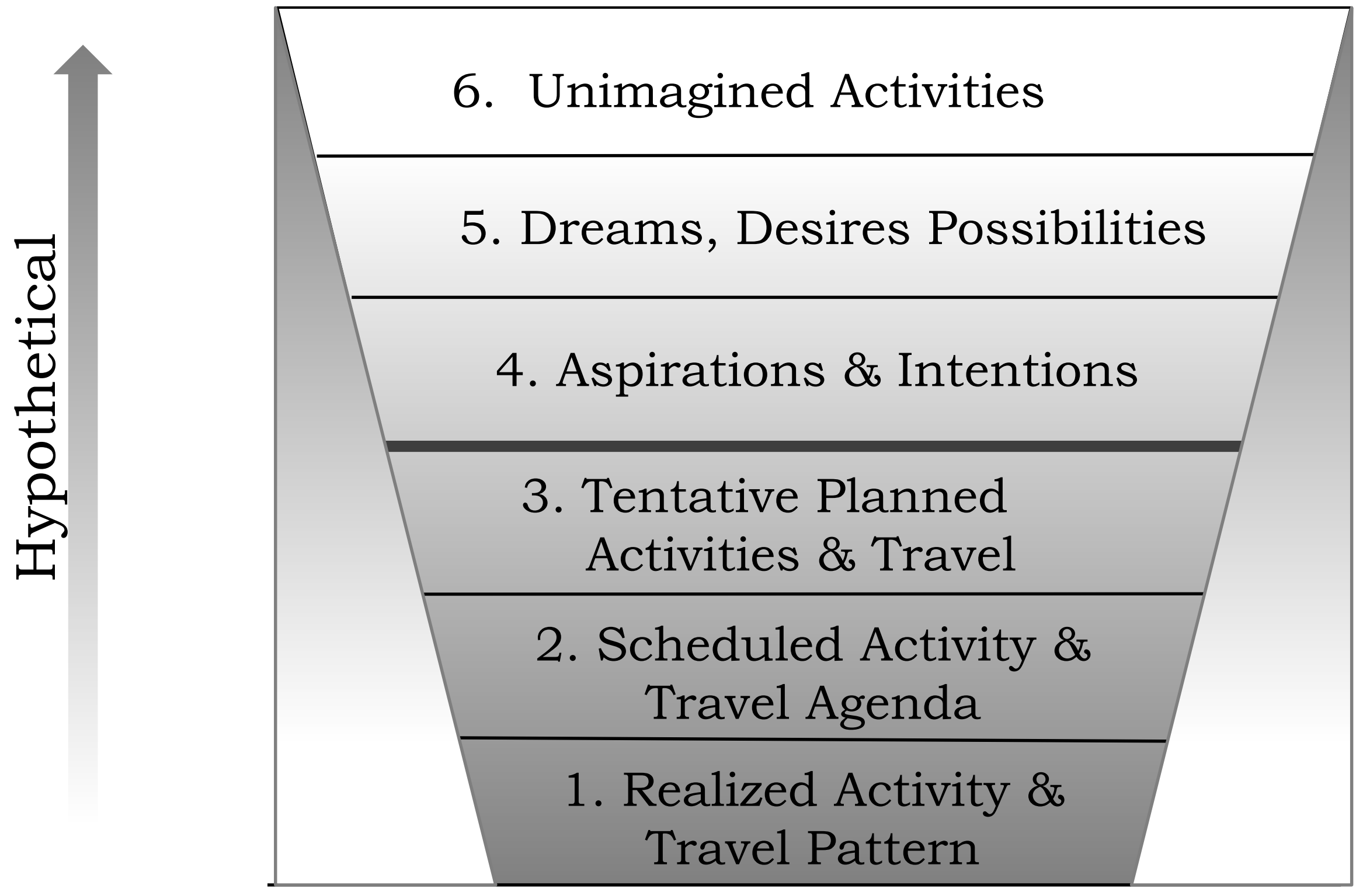




\section{Conclusions}

Our current theories, data collection, and methods are inadequate.

We need a more theoreticallysound definition of demand.

Theoretical exploration of the origins of activity demand from multiple disciplines could enrich and improve our efforts to plan for the future.

Understand unmet needs and how transportation policies, other programs and innovations may address demand.

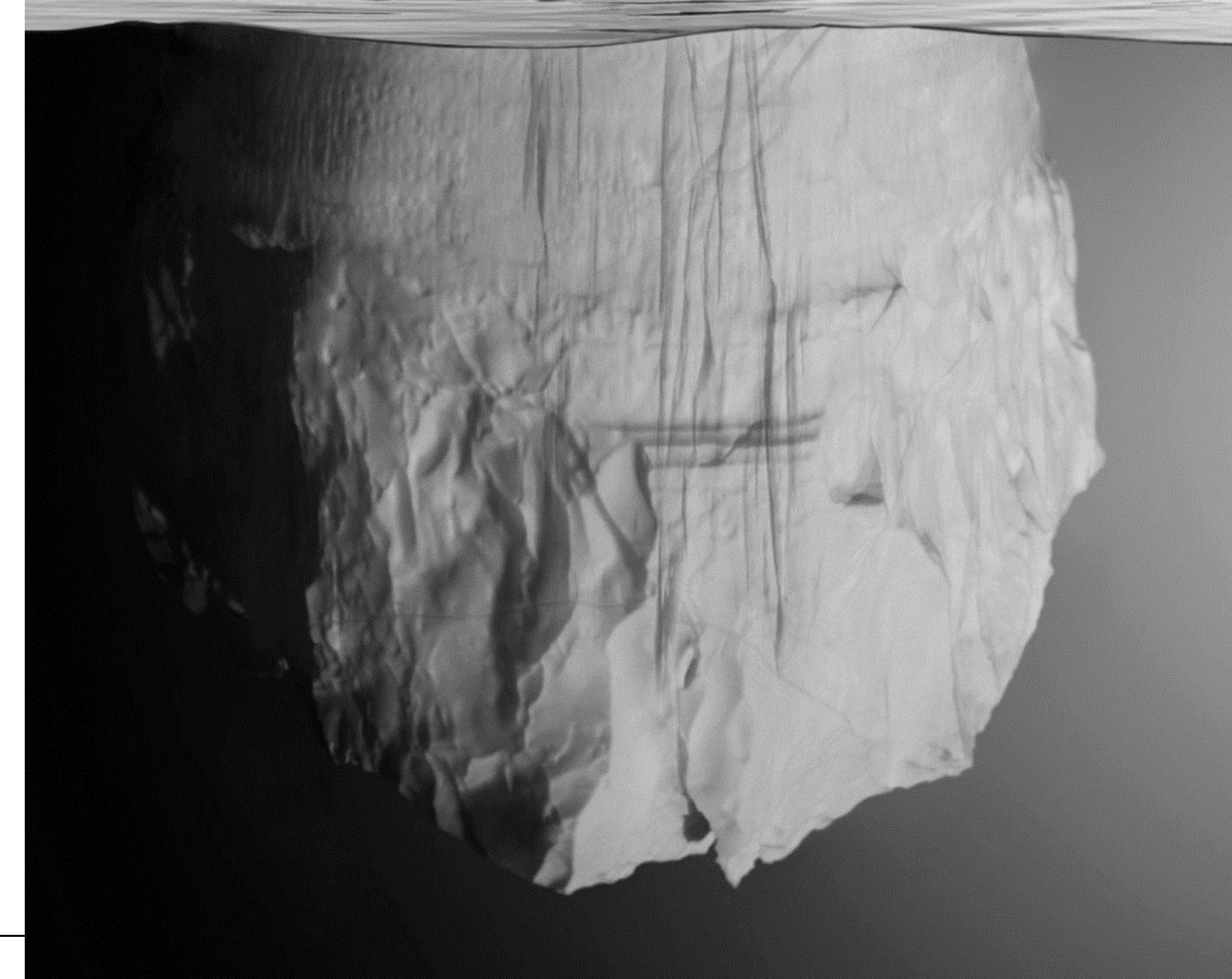




\section{QUESTIONS?}

Kelly J. Clifton

kclifton@pdx.edu 